\title{
Israel's Principal Preparation Policy
}

\author{
Haim Shaked ${ }^{1,2, *}$ \\ ${ }^{1}$ Graduate program, Orot Israel College, Rehovot, Israel \\ ${ }^{2}$ Graduate program, Jerusalem College, Jerusalem, Israel \\ *Correspondence: E-mail: haim.shaked2@gmail.com
}

Received: November 7, 2014

Accepted: December 5, 2014 Online Published: December 15, 2014

doi:10.5430/wje.v4n6p78

URL: http://dx.doi.org/10.5430/wje.v4n6p78

\begin{abstract}
This study explores the official policy of the state of Israel in regard to principal preparation programs, a topic which has hardly been investigated so far and has gone through significant change in recent years. Public documents from Israel were explored. Document analysis was a three-stage process - condensing, coding and categorizing. The analysis was based on interpretation of the documents collected, attempting to detect explicit and implicit meanings concerning the topic at hand. Findings show that the topics covered in principal preparation under the current policy are meant to be largely related to instructional leadership; the teaching methods are supposed to be based on active learning with a practical emphasis; and the participants are to be both carefully selected and encouraged to undertake the position of principal. This policy is consistent with the existing research; however, there are some concerns worthy of the attention of the authorities concerned.
\end{abstract}

Keywords: principal preparation; instructional leadership; foreign countries

\section{Introduction}

A school principal is a decisive factor in developing a high performing school. Principal effectiveness is crucial to improving student achievement, second only to classroom instruction among all the school-related factors contributing to what students learn at school. The quality of the principal alone accounts for about a quarter of a school's impact on student achievement (Marzano et al., 2005; Nettles \& Herrington, 2007; Seashore-Louis et al., 2010; Soehner \& Ryan, 2011). In addition, principal leadership is a key factor in school change; without skilled leadership there is little chance of real change (Bryk et al., 2010; Leithwood et al., 2004).

Principals' quality is highly dependent on the quality of their preparation experience (Baker et al., 2007; Hernandez et al., 2012; Hess \& Kelly, 2005). Thus, principal preparation programs deserve much attention. Is this actually so in reality? A decade ago researchers claimed that the body of research on this topic was limited and insufficient (Lashway, 2003; Murphy, 2002; Murphy \& Vriesenga, 2004). In order to determine whether this has changed during the last decade, a comprehensive examination is required; however, at first glance it does appear as though research in this field has increased.

Principal preparation programs differ from one place to the other. In recent years the local characteristics of these preparation programs in various states around the world are being reviewed and discussed, such as in various U.S. states (Black, 2011; Browne-Ferrigno, 2013), in Canada (Winton \& Pollock, 2013), in England and Scotland (Cowie \& Crawford, 2007; Crawford, 2012), in China (Yan \& Ehrich, 2009), in Kenya and Tanzania (Onguko et al., 2008), and elsewhere. The goal of this study is to explore Israel's official policy in regard to principal preparation programs, which has changed significantly in recent years but has hardly been investigated so far.

\section{Theoretical Background}

In recent years, researchers and practitioners alike have criticized principal preparation programs for failing to adequately prepare prospective educational leaders for their roles, claiming that these programs do not produce qualified principals who are capable of running schools successfully (e.g. Azzam, 2005; Darling-Hammond et al., 2007; Hernandez et al., 2012; Hess \& Kelly, 2007; Tirozzi, 2004; Tucker, 2003). Their criticism focused on three 
main issues: the relevance of the topics covered in preparation programs; the effectiveness of the teaching methods used in them; and the quality of participants. The theoretical background which follows will review these issues.

\subsection{Topics}

One of the main arguments against principal preparation programs pertains to the subjects studied in these programs, claiming that existing programs do not train principals to deal with contemporary challenges. Farkas et al. (2003), for example, noted that $72 \%$ of superintendents and $67 \%$ of school principals agree that "typical leadership programs in graduate schools of education are out of touch with the realities of what it takes to run today's school districts" (p. 39). Among these contemporary challenges is the issue of accountability, meaning that school leaders are expected to demonstrate bottom-line results. This issue is extremely important, as expressed by Hess and Kelly (2007, p. 35): "preparation has not kept pace with changes in the larger world of schooling, leaving graduates of principal preparation programs ill-equipped for the challenges and opportunities posed by an era of accountability".

Accountability in education is defined as "demonstrating the worth and use of public resources" (Lewis et al., 2001, p. 74) or as "responsibility for the decisions and capability to explain to others or the public all undertaken activities to carry out what was obliged to do; to ensure reaching or making progress towards planned objectives or targets" (Wojtczak, 2002, p. 216). The dominance of accountability in the last decade is largely a result of the United States' Act of Congress "No Child Left Behind," which requires schools to pass yearly standardized tests in order to measure students' accomplishments. These tests are the primary means for determining whether schools are meeting the standards they are required to meet. If the required improvements are not achieved, the schools may face decreased funding and other penalties (Hayes, 2008; Hess \& Petrilli, 2006). However, the increasing demands for accountability are common not only in the U.S. but also throughout the world (Levinson, 2011; West et al., 2011).

The outcome-based accountability approach changed the meaning of school leadership. Each school's staff is currently accountable for ameliorating its students' academic outcomes, and more than anyone else it is the school principal who is expected to demonstrate positive results in terms of the students' achievements. Thus, today's school principals must combine the traditional school leadership duties, such as teachers' recruiting and retaining, budgeting, scheduling and facilities maintenance, with the additional challenge of deep involvement in teaching and learning issues that directly affect student achievements (Cotton, 2003). In essence, current school principals have to see instructional leadership and school improvement as their main role (DiPaola \& Hoy, 2008; Marzano et al., 2005).

Principal preparation programs should be changed accordingly, i.e. they must teach instructional leadership and its practices. These practices are diverse, including modeling effective instruction, mentoring others to understand effective instruction, and monitoring of student performance data (Southworth, 2009); maintaining a tight instructional focus sustained over time; routinizing accountability for practice and performance in face-to-face relationships; reducing isolation and opening practice to direct observation, analysis and criticism; and exercising differential treatment based on performance and capacity, not on volunteerism (Elmore, 2000). The practices of instructional leadership have to be part and parcel of principal preparation programs, but at present they are not (Darling-Hammond et al., 2007; Hess \& Kelly, 2007).

\subsection{Teaching Methods}

One more key argument about principal preparation programs is that the methods of teaching used are overly didactic and not sufficiently interactive. The programs lack high-quality learning opportunities and active student-centered instruction, such as the use of case studies, problem-based learning and action research (American Association of Colleges for Teacher Education, 2001; Elmore, 2000; Hernandez et al., 2012; Hess \& Kelly, 2007; Murphy \& Vriesenga, 2004).

In this context, researchers claim that preparation programs are not practical enough. They place too much emphasis on theory at the expense of teaching practical application (Martin \& Papa, 2008); the faculty members have little field experience as leaders, and the connection between theory and practice is insufficient (Darling-Hammond et al., 2007; Levine, 2005). Field-based experiences are limited and are not used as significant learning resources for prospective principals; they are often loosely linked to academic coursework, which is structured around discrete domains of educational administration, rather than being organized as an integrated set of learning opportunities which build upon and support the field-based experiences (Lauder, 2000; Reames, 2010).

On the other hand, researchers have listed characteristics of effective preparation programs, such as clear focus and values as the basis of coherently organized programs; standards-based curriculum; and cohort groups that create opportunities for collaboration and teamwork (Davis et al., 2005; Murphy \& Vriesenga, 2004; Peterson, 2002). 


\subsection{Students}

An additional claim as to the drawbacks of current principal preparation programs is made in regard to the lack of rigorous recruitment and selection of participants (Darling-Hammond et al., 2007; Davis et al., 2005; Hernandez et al., 2012).This argument should be examined in wake of the decline in the number and quality of principalship candidates which awakens the concern of both researchers and practitioners (e.g. Gajda \& Militello, 2008; Nelson, 2010; Pijanowski \& Brady, 2009; Pijanowski et al., 2009).

In the last fifteen years, American public schools have been facing a critical shortage of quality candidates for principal positions (Fenwick \& Pierce, 2001; Pounder \& Merrill, 2001; Whitaker, 2001), in urban, suburban and rural schools (Quinn, 2002). This shortage is attributed to the retirement of aging principals, to increased principal mobility, and to the accountability approach which "undermines the capacity of incoming and outgoing principals to lead their schools" (Fink \& Brayman, 2006, p. 83). The shortage is felt in other countries too, such as in Australia (Barty et al., 2005) and England (Bush, 2011).

The need to provide highly qualified school principals during a time of shortage has resulted in changes in preparation policy, such as creation of alternative principal licensing programs, which provide an opportunity for individuals to begin actual principalship without formal administrative preparation (Hickey-Gramke \& Whaley, 2007), and encouragement of educators who have clearly demonstrated leadership talent to participate in principal preparation programs rather than recruiting participants through broadly targeted mailings, visits, or calls to educators (Pounder \& Crow, 2005).

\subsection{Principal Preparation Programs in Israel}

In wake of the prevalent criticism on principal preparation programs reviewed above, many preparation programs have introduced reforms aimed at better preparing future school leaders (Weiler \& Cray, 2012). What is the current situation in Israel? Research on principal preparation policy in Israel is virtually non-existent. Two decades ago, Chen (1996) described the preparation of principals in Israel, noting that "academic preparation of principals in Israel is a fairly new commodity" (p. 287). A decade ago Gutterman (2004) noted that principal preparation in Israel is undergoing change, since the Ministry of Education requires principalship candidates to participate in preparation programs. In the intervening years, many changes have occurred. A few years ago Oplatka and Waite (2010) described the new construction of principal preparation programs in Israel and its underlying principles and historical background, raising some questions as to its applicability and quality in terms of practical suggestions and expected teaching strategies. However, the ongoing development of the Israeli principal preparation policy renders their article somewhat outdated. The goal of this article is to explore the current policy of Israeli authorities in regard to principal preparation in regard to principal preparation as compared with the existing recommendations derived from research in this area.

\section{Methodology}

Alongside interviews and observations, documents are also a valuable source of qualitative data, being that "documents are part of the fabric of our world" (Love, 2003, p. 83). Documents may be useful in various areas of educational research. For example, Jenkins (2009) used documents from various countries to investigate conceptual foundations of science curriculum reform in schools; Gregg (2011) explored what the position statement of the National Association for the Education of Young Children articulates regarding children with disabilities included in early childhood classrooms; and Tupper (2008) examined a high school drug education text to discern its underlying ideological commitments and political dispositions.

Documents are often used as secondary sources in qualitative research, since they are considered to be "valuable resources for confirming insights gained through interviews and observations" (Merriam, 2009, p. xi). One may claim that this is regrettable, since documents have many advantages as a source of research (Bowen, 2009), making things visible and traceable (Prior, 2003). At any rate, some areas can be investigated primarily through documents, and that is the case with the subject of this study, which deals with the official policy of a state in regard to principal preparation. Thus, this study is based on document analysis.

Bogdan and Biklen (2007) classify existing documents on educational research into three basic categories: personal documents - documents created by an individual; official documents - documents produced by institutions; and popular culture documents - mass-consumed materials, such as movies, music albums, books and advertisements. This study required focusing on official documents, which are public documents, i.e. documents produced for public consumption (Payne \& Payne, 2004). 
The current study explored documents of 'Avney Rosha' ('Capstones'), an institute that was appointed to lead school principals' development in Israel, and documents of the Israeli Ministry of Education. Data analysis was a three-stage process - condensing, coding and categorizing. Once documents were collected, I found that not all the material collected could serve the purpose of the study, and a sorting process was necessary (Miles, Huberman, \& Saldaña, 2014). Thus, in the first stage of analysis (condensing), I looked for the portions of data that in any way related to the topic of this study. In the second stage (coding), each segment of relevant data was coded by the aspect of the subject it expressed (Gibbs, 2007). After capturing the essence of portions of data in the second stage, in the third stage (categorizing), I clustered similar portions of data to generalize their meanings and derive categories, reworking categories to reconcile disconfirming data with the emerging analysis.

Document analysis seeks to clarify not only what the author meant, but also to ponder the meaning of the document's actual existence. Documents should be analyzed not only by dealing with their contents, as produced by human beings, but also by dealing with their function within relational networks (Prior, 2008). Analysis of documents in this study was based on interpretation of the documents collected, which aimed at detecting explicit and implicit meaning concerning the topic at hand.

\section{Findings}

Israel's policy in regard to principal preparation has undergone significant development in recent years. According to the current policy, the topics covered in principal preparation are largely related to instructional leadership; the teaching methods are based on involvement and implementation, emphasizing field-based experiences; and the participants are both carefully selected and encouraged to undertake the principal position. The findings chapter will review these issues.

\subsection{Topics}

The topics covered in Israeli principal preparation programs stem from the perception of the school principal's role in the state of Israel, which has been clarified in recent years. In 2007 the Israeli Ministry of Education established an institute named 'Avney Rosha' ('Capstones') appointed to lead the whole topic of school principals' development in Israel. The purpose of this institute is to promote the Israeli educational system and to improve its achievements by mobilizing school principals as a leading professional community, with its main areas consisting of principal preparation programs and ongoing learning among school principals.

This institute published a constitutive document titled 'perception of the principal's role in the state of Israel' (Avney Rosha, 2008), defining a conceptual and practical framework for the role of school principals in Israel and elucidating principals' key areas of responsibility as educational leaders. The concept presented in this document reflects a clear priority: "the main function of school principals is to serve as an educational and pedagogic leader for the school in order to enhance the education and learning of all pupils" (p. 9). The school is responsible for educating students, instilling in them a desire for knowledge, promoting their scholastic autonomy through self-regulated learning and enabling them to attribute meaning to what they learn. Thus, school's top priority must be to constantly improve the education, learning, and achievements of all students. As a pedagogic leader, the principal plans, leads, and participates in the school's key educational tasks, in collaboration with the school community.

Four additional areas of management enable and support this function: designing the school's future image developing vision and bringing about change; leading the staff and nurturing its professional development; focusing on the individual pupil; and managing the relationship between the school and the community. As a school leader, the principal must be able to grasp a variety of dimensions and aspects of the school system and create close links between these factors to ensure the success of all students. According to this concept, expected outcomes from school principals at the early stages of their career were defined (Avney Rosha, 2010). Several Knesset Members proposed to turn this concept into a law (Knesset, 2011).

This concept of the principal's role was the basis for redesigning the Israeli principal preparation programs. After two years of initial experience, Avney Rosha (2012) published a new tender to run principal preparation programs, which was addressed to academic institutions, allowing them to recommend themselves as preparation program administrators. The tender listed what it takes to run a principal preparation program, detailing all the aspects of these programs such as principles, structure, contents and budget. This tender stated that "a central axis of the preparation program will be instructional leadership. The proposed plans should provide updated and practical knowledge in this field, particularly about the connection between improving education, teaching, learning and student achievement, and the role of the school principal" (p. 7). 
Subsequently, the tender details four main topics to be covered in principal preparation programs. The first topic is improving education, teaching and learning. This topic takes up more than half the hours of the entire program, and includes the following subtopics: effective teaching and learning; pedagogical diagnosis of the school; evaluation, observation and feedback to teachers; and data-based pedagogical management. The second topic is management of the school staff and its professional development; the third topic is designing of the future image of the school; and the fourth topic is management of the organization, i.e. management of the more technical aspects of the school such as budget, time, and the like.

Expected results for the program's graduates were defined, such as "the prospective principal will know theories, concepts and practices of school improvement processes focused on teaching and learning"; "the prospective principal will understand the characteristics of effective classroom pedagogical processes"; "the prospective principal will be capable of analyzing educational and pedagogical documents such as vision declarations, work plans, programs, and external reports"; "the prospective principal will be well-versed in theories, concepts and practices of effective learning for teachers within as well as outside the school" and "the prospective principal will understand the relationship between systemic elements of the school such as personnel, budget and the organizational aspects, and realization of the school's pedagogic goals and objectives".

Based on this tender, the Israeli Ministry of Education (2013a; 2013b) published guidelines regarding the curriculum and the framework of principal preparation programs. The guidelines stipulate that instructional leadership should be pivotal in principal preparation programs, providing up-to-date and useful knowledge linking improvement of teaching and learning to the performance of the school principal. This reflects a shift from previous years, when principal preparation programs focused on knowing the educational system and its rules of operation, as well as on developing participants' educational leadership perspective, and the principal's role as head of the educational institution and a team leader (Israeli Ministry of Education, 2007a; 2007b; 2009); later it focused on improving teaching and learning, designing the image of the future of the school, team leadership and professional development, data-based management, and budget and resources management (Israeli Ministry of Education, 2010; 2011; 2012a); and as mentioned above, according to the latest guidelines, instructional leadership is the main axis of the principal preparation programs.

It should be noted that in 2014 the Israeli Education Minister announced the launching of a comprehensive educational program named "Israel moves up a grade: Moving on to meaningful learning." The term 'meaningful learning' is meant to specify learning situations in which the student raises questions, finds sources of information, processes information and creates new knowledge relevant to his or her personal world as well as to life in the 21st century technological era. The purpose of meaningful learning is to develop thinking, creative and self-learning abilities, while encouraging personal growth and community involvement (Israeli Ministry of Education, 2014a). According to the Education Minister, this program seeks to decrease memorization and knowledge measuring, while increasing meaningful discourse between teacher and student as well as value-based education. It aims to enable all students to realize their potential and express their individuality, reinforcing outstanding students; in addition, it aspires to narrow the gaps within the school system, such as the gap between central and peripheral areas (Piron, 2014).

This program, which emphasizes community involvement and advocates reducing external exams (Israeli Ministry of Education, 2014b), may change the concept of the school principal's role.

\subsection{Teaching Methods}

The above-mentioned new tender to run principal preparation programs (Avney Rosha, 2012) requests that these programs consist of two parts: 250 hours of classroom learning at the academic institution, and 150 hours of field learning at a host school, both of which must include experiential learning. The programs are to provide rich opportunities for learning, based on involvement, experience and implementation, seeing to it that the theoretical knowledge imparted relates to and complements the experiential learning.

A variety of teaching and learning methodologies should be practiced, mainly ones involving active and effective experiential learning, such as problem-based learning, case studies, project-based learning, simulations, video-based learning and distance learning. Out of the classroom learning time, 130 hours should be experiential learning, i.e. group learning, cooperative learning and peer learning. This learning will be done in small groups of up to 24 students. Twenty hours are to be dedicated to mentoring, which is given to each prospective principal individually by a staff member. These hours are focused on planning the mode of learning as well as the relationship between the various learning components. 
The host schools are to demonstrate instructional leadership at its best. Their principals participate in specialized professional development. The learning in the host school consists of 110 hours of observations, conversations and interviews, and 40 hours of training by the school principal. The learning at the host school should emphasize instructional leadership, dealing with topics such as management and monitoring of programs aimed at improving instruction and learning; theories pertaining to school improvement, including the complexity of putting them into practice; understanding the principal's main points of power and influence; instruction and teaching strategies, teacher's learning strategies, and evidence-and-data-based work.

Based on this tender, the guidelines of the Israeli Ministry of Education (2013a; 2013b) regarding principal preparation programs stipulate that one of the principles of the program is experiential learning, which is based on involvement, experience and implementation in the host schools as well as in the academic institution. It should be noted that in the previous tender to run principal preparation programs (Avney Rosha, 2009) the scope of the principal preparation program was 600 hours, including 300-350 hours of classroom learning at the academic institution and 150-200 hours of field learning at the host school, as well as 50 hours of peer workshops and 30 hours of mentoring. Thus, the new tender (Avney Rosha, 2012) has reduced the duration of the principal preparation program by a third.

\subsection{Students}

The Israeli Ministry of Education (2012b) has changed the entrance requirements for school principals: since 2014 only holders of a master's degree can qualify. Accordingly, admission requirements for principal preparation programs have changed, so that a master's degree is required for them as well. For this reason, the preparation program is focused on acquiring practical rather than theoretical knowledge, which was supposedly acquired during the master's degree studies (Avney Rosha, 2012).

One more admission requirement to principal preparation programs is having actually worked as a teacher. A teacher on sabbatical or on leave cannot participate in the program; a certification of a school principal indicating that the candidate is going to teach at his or her school that year is a prerequisite for starting the program (Israeli Ministry of Education, 2012a). The Israeli Ministry of Education funds most of the program, with participants paying only a quarter of the actual cost, amounting to the equivalent of about one thousand dollars (Avney Rosha, 2012).

One of the goals set for the principal preparation programs was to increase participants' commitment to the role of school principal, since some people enroll in them for the sake of self-enrichment or in order to add a lucrative tinge to their resume, while others do begin with the will to be principals, but start to waver over time. Thus, preparation programs should encourage participants' to undertake this role (Israeli Ministry of Education, 2013a). This is to be one of the major issues addressed in the mentoring hours (Avney Rosha, 2012).

\section{Discussion}

The policy of the state of Israel regarding principal preparation is consistent with the findings of recent studies in terms of the topics to be covered in preparation programs, the teaching methods to be used, and the approach to be taken toward participants. In regard to the topics covered, Israeli principal preparation programs focus on instructional leadership, as according to the guidelines of the Israeli Ministry of Education (2013a; 2013b) this should be the linchpin of such programs. This priority is based on the perception of the principal's role in Israel, which was defined by Avney Rosha (2008). However, this perception employed two terms - education and pedagogy, stating that "the main function of a school principal is to serve as an educational and pedagogic leader for the school in order to enhance the education and learning of all pupils" (p. 9). According to this definition the school principal should deal with 'pedagogy', meaning the area of teaching and learning, but must first engage in 'education', which in Hebrew connotes moral education. The guidelines of the Israeli Ministry of Education (2013a; 2013b) actually omitted the educational aspect and focused on the instructional one.

Emphasizing instructional leadership in principal preparation is the recommendation of leading researchers (Darling-Hammond et al., 2007; Hess and Kelly, 2007). This recommendation is based on the understanding that ours is an era of accountability, which is characterized by high expectations from school leaders alongside frequent changes in educational systems (e.g. Carter, 2012; Comber \& Nixon, 2011; Jennings, 2010). To accommodate this era of result-based accountability, school principals need the capacity to develop high levels of learning for all students (Browne-Ferrigno, 2007); thus, instructional leadership should be part and parcel of principal preparation programs.

The Israeli Ministry of Education's (2013a; 2013b) assertion that instructional leadership is a top priority is relatively 
new; in earlier years, the development of educational-managerial leadership was only second on the list of the three objectives of the program (Israeli Ministry of Education, 2007a; 2007b; 2009); later it became the first of five objectives (Israeli Ministry of Education, 2010; 2011; 2012a), and at present it is considered to be the main one.

As for teaching methods, the Israeli principal preparation policy considers theoretical knowledge as complementary to experiential learning; thus, learning that is based on involvement, experience and implementation is recommended. As explained above, preparation programs focus on practical rather than theoretical knowledge, which should be acquired during master's degree studies (Avney Rosha, 2012), and in order to link theory to practice, participants of preparation programs must be working teachers at the time of their preparation (Israeli Ministry of Education, 2012a). This is in compliance with researchers' suggestions to employ student-centered instruction (Elmore, 2000; Hernandez et al., 2012; Hess \& Kelly, 2007; Murphy \& Vriesenga, 2004) and to engage largely in practice, linking theory and practice (Darling-Hammond et al., 2007; Levine, 2005). In addition, the time spent in the host school is a significant part of the Israeli principal preparation programs, constituting about forty percent of the program. As aforesaid, it is important that field-based experiences be a main part of principal preparation programs (Lauder, 2000; Reames, 2010).

As for the participants in principal preparation programs, the Israeli policy works both ways, raising the level of participants and at the same time increasing their number. The requirement for a master's degree stems from the attempt to raise the level of participants, responding to criticism concerning the low quality of aspiring principals (Darling-Hammond et al., 2007; Davis et al., 2005; Hernandez et al., 2012); and in order to increase the number of participants interested in the program, the scope of the program was reduced by a third. In addition, payment for the program has been subsidized, so that it is relatively inexpensive. One of the goals set for principal preparation programs is to deepen participants' commitment to school leadership. All these measures combined help to cope with the shortage of candidates for principal positions sensed worldwide (Barty et al., 2005; Bush, 2011; Fenwick \& Pierce, 2001; Pounder \& Merrill, 2001; Quinn, 2002; Whitaker, 2001).

The correlation between Israel's policy regarding principal preparation and the findings of recent studies is satisfactory; however, some issues are worthy of the attention of the authorities concerned. First, the instructional leadership is at risk of losing its status because of the new flag that has recently begun to be hoisted by the Israeli Ministry of Education, titled "Moving on to meaningful learning" (Israeli Ministry of Education, 2014a). This notion may change the current perception of the role of school principal, placing less emphasis on standards and achievements. Frequent changes in the policies of the Ministry of Education are detrimental to the work of the Israeli education system in general, and to the development of clear priorities for principal preparation in particular. The fact that principal preparation is dealt with by an independent body rather than by the Ministry of Education itself may reduce the turmoil in this area, as there is a relatively high turnover of Education Ministers in Israel, and therefore relatively frequent changes in this ministry's policy.

In regard to the time spent in the host school, merely increasing the amount of time spent in the field is not enough; the prospective principals' stay in the field should be well structured and relevant to their development. It should be linked to academic coursework, which is organized as an integrated series of learning opportunities that build upon and support the field-based experiences. Moreover, in the current format the field-based experience involves mainly observations. This experience may become more beneficial if it will involve practical training, where aspiring principals are expected to put the knowledge they have acquired into practice.

In addition, the decision to shorten the duration of the principal preparation program may turn out to be problematic. Learning is a process which requires time and patience; in many cases shortcuts are impossible. Shortening the development journey of aspiring school principals may result in preparation program graduates that did not undergo satisfactory professional development processes.

This study has provided new data compared to prior research; however, it has several limitations. Firstly, the goal of this study was to explore the policy of Israeli authorities in regard to principal preparation, compared to the existing body of knowledge in this area; actual implementation of this policy was not explored. Further research should explore the extent to which this policy is actually implemented in principal preparation programs, as well as study its results. Secondly, this study presented the existing policy; further research should explore the process through which this policy has been formed. In addition, the ongoing development of the Israeli principal preparation policy requires further replications of this study every so often. 


\section{References}

American Association of Colleges for Teacher Education (2001). PK-12 educational leadership and administration (white paper). Washington, DC: American Association of Colleges for Teacher Education.

Avney Rosha - The Israel Institute for School Leadership (2008). Perception of the principal's role in the state of Israel: Report by the professional committee to formulate policy recommendations for the Ministry of Education. Jerusalem, Israel: Avney Rosha.

Avney Rosha - The Israel Institute for School Leadership (2009). Tender 1/8.09: Development and application of a program for "Avney Rosha" institute to train school principals in Israel (Hebrew). Retrieved from http://avneyrosha.org.il/Train/KolKore/\%D7\%A7\%D7\%95\%D7\%9C\%20\%D7\%A7\%D7\%95\%D7\%A8\%D7\% 90.pdf

Avney Rosha - The Israel Institute for School Leadership (2010). Expected outcomes from school principals at the start of their career ( $3^{\text {rd }}$ ed.). Jerusalem, Israel: Avney Rosha.

Avney Rosha - The Israel Institute for School Leadership (2012). Tender 2/2012: Development and application of "the new program for principal training in the academic institutions" of Avney Rosha institute (Hebrew). Retrieved from avneyrosha.org.il/Train/2012/bid.doc

Azzam, A. M. (2005). The unprepared administrator. Educational Leadership, 62(8), 88-89.

Baker, D. B., Orr, M. T., \& Young, M. D. (2007). Academic drift, institutional production, and professional distribution of graduate degrees in educational leadership. Educational Administration Quarterly, 43(3), 279-318. http://dx.doi.org/10.1177/0013161X07303320

Barty, K., Thomson, P., Blackmore, J., \& Sachs, J. (2005). Unpacking the issues: Researching the shortage of school principals in two states in Australia. Australian Educational Researcher, 32(3), 1-18. http://dx.doi.org/10.1007/BF03216824

Black, W. (2011). Who are we? Collaborative inquiry and the description of one state's principal preparation programs. International Journal of Educational Leadership Preparation, 6(2), 1-17.

Bogdan, R. C., \& Biklen S. K. (2007). Qualitative research for education: An introduction to theory and methods (5th ed.). Boston, MA: Pearson.

Bowen, G. A. (2009). Document analysis as a qualitative research method. Qualitative Research Journal, 9(2), 27-40. http://dx.doi.org/10.3316/QRJ0902027

Browne-Ferrigno, T. (2007). Developing school leaders: Practitioner growth during an advanced leadership development program for principals and administrator-trained teachers. Journal of Research on Leadership Education, 2(3), 1-30.

Browne-Ferrigno, T. (2013). Mandated preparation program redesign: Kentucky case. Journal of Research on Leadership Education, 8(2), 168-190. http://dx.doi.org/10.1177/1942775113490934

Bryk, A. S., Sebring, P. B., Allensworth, E., Luppescu, S., \& Easton, J. Q. (2010). Organizing Schools for Improvement: Lessons from Chicago. Chicago, IL: University of Chicago Press.

Bush, T. (2011). Succession planning and leadership development for school principals: Comparing English and South African approaches. Compare: A Journal of Comparative and International Education, 41(6), 785-800.

Carter, H. M. (2012). Institutionalization of caring in an era of accountability: Creating a supportive environment for at-risk students' retention in high school and access to college. New Educator, 8(2), 177-193. http://dx.doi.org/10.1080/1547688X.2012.670568

Chen, M. (1996). Academic preparation of principals in Israel: Empowering dynamic school leadership. International Journal of Educational Reform, 5(3), 287-296.

Comber, B., \& Nixon, H. (2011). Critical reading comprehension in an era of accountability. Australian Educational Researcher, 38(2), 167-179. http://dx.doi.org/10.1007/s13384-011-0022-z

Cotton, K. (2003). Principals and student achievement. Alexandria, VA: Association for Supervision and Curriculum Development.

Cowie, M., \& Crawford, M. (2007). Principal preparation: Still an act of faith? School Leadership \& Management, 27(2), 129-146. http://dx.doi.org/10.1080/13632430701237198 
Crawford, M. (2012). Novice head teachers in Scotland: Competing expectations. School Leadership \& Management, 32(3), 279-290. http://dx.doi.org/10.1080/13632434.2012.669365

Darling-Hammond, L., LaPointe, M., Meyerson, D., Orr, M. T., \& Cohen, C. (2007). Preparing School Leaders for a Changing World: Lessons from Exemplary Leadership Development Programs. Stanford, CA: Stanford Educational Leadership Institute.

Davis, S., Darling-Hammond, L., LaPointe, M., \& Meyerson, D. (2005). School leadership study: Developing successful principals. Stanford, CA: Stanford Educational Leadership Institute.

DiPaola, M. F., \& Wayne, K. H. (2008). Principals improving instruction: Supervision, evaluation, and professional development. Boston, MA: Pearson Education.

Elmore, R. F. (2000). Building a new structure for school leadership. Washington, DC: The Albert Shanker Institute.

Farkas, S., Johnson, J., \& Duffett, A. (2003). Rolling up their sleeves: Superintendents and principals talk about what's needed to fix public schools. New York, NY: Public Agenda.

Fenwick, L. T., \& Pierce, M. C. (2001). The principal shortage: Crisis or opportunity? Principal, 80(4), 25-32.

Fink, D., \& Brayman, C. (2006). School leadership succession and the challenges of change. Educational Administration Quarterly, 42(1), 62-89. http://dx.doi.org/10.1177/0013161X05278186

Gajda, R., \& Militello, M. (2008). Recruiting and retaining school principals: What we can learn from practicing administrators. AASA Journal of Scholarship \& Practice, 5(2), 14-20.

Gibbs, G. R. (2007). Analyzing qualitative data: London, UK: Sage.

Gregg, K. (2011). A document analysis of the National Association for the Education of Young Children's developmentally appropriate practice position statement: What does it tell us about supporting children with disabilities? Contemporary Issues in Early Childhood, 12(2), 175-186. http://dx.doi.org/10.2304/ciec.2011.12.2.175

Gutterman, J. (2004). On the way to desirable preparation: Trends and changes in school principals' preparation (Hebrew). Education and Related Issues, 26, 139-149.

Hayes, W. (2008). No child left behind: Past, present, and future. Lanham, MD: Rowman \& Littlefield.

Hernandez, R., Roberts, M., \& Menchaca, V. (2012) Redesigning a principal preparation program: A continuous improvement model. International Journal of Educational Leadership Preparation, 7(3). Retrieved from http://files.eric.ed.gov/fulltext/EJ997446.pdf

Hess, F. M., \& Kelly, A. P. (2005). The accidental principal: What doesn't get taught at ed schools? Education Next, 5(3), 34-40.

Hess, F. M., \& Kelly, A. P. (2007). Learning to lead: What gets taught in principal preparation programs. Teachers College Record, 109(1), 244-274.

Hess, F. M., \& Petrilli, M. J. (2006). No child left behind primer. New York, NY: Peter Lang.

Hickey-Gramke, M., \& Whaley, D. C. (2007). Essential elements and emergent issues for alternative principal licensing: Recommendations for policy design and implementation. AASA Journal of Scholarship \& Practice, 4(3), 20-25.

Israeli Ministry of Education (2007a). CEO guidelines (Hebrew). Retrieved from http://cms.education.gov.il/EducationCMS/Applications/Mankal/EtsMedorim/8/8-4/HodaotVmeyda/H-2007-58-4-1.htm

Israeli Ministry of Education (2007b). CEO guidelines (Hebrew). Retrieved from http://cms.education.gov.il/EducationCMS/Applications/Mankal/EtsMedorim/8/8-4/HodaotVmeyda/H-2008-48-4-1.htm

Israeli Ministry of Education (2009). CEO guidelines (Hebrew). Retrieved from http://cms.education.gov.il/EducationCMS/Applications/Mankal/EtsMedorim/8/8-4/HodaotVmeyda/H-2009-58-4-1.htm

Israeli Ministry of Education (2010). CEO guidelines (Hebrew). Retrieved from http://cms.education.gov.il/EducationCMS/Applications/Mankal/EtsMedorim/8/8-4/HodaotVmeyda/H-2010-78-4-2.htm 
Israeli Ministry of Education (2011). CEO guidelines (Hebrew). Retrieved from http://cms.education.gov.il/EducationCMS/Applications/Mankal/EtsMedorim/8/8-4/HodaotVmeyda/H-2011-58.4-1.htm

Israeli Ministry of Education (2012a). CEO guidelines (Hebrew). Retrieved from http://cms.education.gov.il/EducationCMS/Applications/Mankal/EtsMedorim/8/8-4/HodaotVmeyda/H-2012-58-4-1.htm

Israeli Ministry of Education (2012b). CEO guidelines (Hebrew). Retrieved from http://cms.education.gov.il/EducationCMS/Applications/Mankal/EtsMedorim/8/8-4/HoraotKeva/K-2012-8-2-84-15.htm

Israeli Ministry of Education (2013a). CEO guidelines (Hebrew). Retrieved from http:/cms.education.gov.il/EducationCMS/Applications/Mankal/EtsMedorim/8/8-4/HodaotVmeyda/H-2013-58-4-1.htm

Israeli Ministry of Education (2013b). CEO guidelines (Hebrew). Retrieved from http://cms.education.gov.il/EducationCMS/Applications/Mankal/EtsMedorim/8/8-4/HodaotVmeyda/H-2013-11-8-4-1.htm

Israeli Ministry of Education (2014a). Moving on to meaningful learning (Hebrew). Retrieved from http://cms.education.gov.il/EducationCMS/Units/LemidaMashmautit/mashmautit/HagdaraMashmautit.htm

Israeli Ministry of Education (2014b). CEO guidelines (Hebrew). Retrieved from http://cms.education.gov.il/educationcms/applications/mankal/etsmedorim/3/3-1/horaotkeva/k-2014-7-4-9-1-47. htm

Jenkins, E. (2009). Reforming school science education: A commentary on selected reports and policy documents. Studies in Science Education, 45(1), 65-92. http://dx.doi.org/10.1080/03057260802681813

Jennings, J. L. (2010). School choice or schools' choice? Managing in an era of accountability. Sociology of Education, 83(3), 227-247. http://dx.doi.org/10.1177/0038040710375688

Knesset (2011). A bill: Educational institution's principal. Retrieved from knesset.gov.il/privatelaw/data/18/3771.rtf

Lashway, L. (2003). Transforming Principal Preparation. Washington, DC: US Department of Education, Office of Educational Research and Improvement.

Lauder, A. (2000). The new look in principal preparation programs. NASSP Bulletin, 84(617), 23-28. http://dx.doi.org/10.1177/019263650008461703

Leithwood, K., Louis, K. S., Anderson, S., \& Wahlstrom, K. (2004). Learning from leadership project: How leadership influences student learning. New York, NY: The Wallace Foundation.

Levine, A. (2005). Educating school leaders. New York, NY: Education School Project.

Levinson, M. (2011). Democracy, accountability, and education. Theory and Research in Education, 9(2), $125-144$. http://dx.doi.org/10.1177/1477878511409622

Lewis, D. R., Ikeda, T., \& Dundar, H. (2001). On the use of performance indicators in Japan's higher education reform agenda. Nagoya Journal of Higher Education, 1, 67-98.

Love, P. (2003). Chapter 6: Document Analysis. In Stage FK \& Manning K (eds), Research in the college context: Approaches and methods. New York, NY: Brunner-Routledge, pp. 83-97.

Martin, G. E., \& Papa, R. (2008). Examining the principal preparation and practice gap. Principal, 88(1),12-14.

Marzano, R. J., Waters, T., \& McNulty, B. A. (2005). School leadership that works: From research to results. Alexandria, VA: Association of Curriculum and Supervision Development.

Merriam, S. B. (2009). Qualitative research: A guide to design and implementation. San Francisco, CA: Jossey Bass.

Miles, M. B., Huberman, M. A., \& Saldaña, J. (2014). Qualitative data analysis: A methods sourcebook (3rd ed.). Thousand Oaks, CA: Sage.

Murphy, J. (2002). Reculturing the profession of educational leadership: New blueprints. Educational Administration Quarterly, 38(2), 176-191. http://dx.doi.org/10.1177/0013161X02382004

Murphy, J., \& Vriesenga, M. (2004). Research in preparation programs in educational administration: An analysis. 
New York, NY: Columbia University Council for Educational Administration.

Nelson, K. (2010). Developing great administrators one teacher at a time. Principal, 89(5), $24-27$.

Nettles, S. M., \& Herrington, C. (2007). Revisiting the importance of the direct effects of school leadership on student achievement: The implications for school improvement policy. Peabody Journal of Education, 82(4), 724-736. http://dx.doi.org/10.1080/01619560701603239

Onguko, B., Abdalla, M., \& Webber, C. F. (2008). Mapping principal preparation in Kenya and Tanzania. Journal of Educational Administration, 46(6), 715-726. http://dx.doi.org/10.1108/09578230810908307

Oplatka, I., \& Waite, D. (2010). The new principal preparation program model in Israel: Ponderings about practice-oriented principal training. Advances in Educational Administration, 11, 47-66. http://dx.doi.org/10.1108/S1479-3660(2010)0000011006

Payne, G., \& Payne, J. (2004). Key concepts in social research. London, UK: Sage.

Peterson, K. D. (2002). The professional development of principals: Innovations and opportunities. Educational Administration Quarterly, 38(2), 213-232. http://dx.doi.org/10.1177/0013161X02382006

Pijanowski, J. C., \& Brady, K. P. (2009). The influence of salary in attracting and retaining school leaders. Education and Urban Society, 42(1), 25-41. http://dx.doi.org/10.1177/0013124509342952

Pijanowski, J. C., Hewitt, P. M., \& Brady, K. P. (2009). Superintendents' perceptions of the principal shortage. NASSP Bulletin, 93(2), 85-95. http://dx.doi.org/10.1177/0192636509343963

Piron, S. (2014). A speech of Education Minister, Rabbi Shai Piron: Israel moves up a grade. Retrieved from gradehttps://www.youtube.com/watch?v=CHvgcoRwzyY

Pounder, D., \& Crow, G. (2005). Sustaining the pipeline of school administrators. Educational Leadership, 62(8), 56-60.

Pounder, D. G., \& Merrill, R. J. (2001). Lost luster. School Administrator, 58, 18-22.

Prior, L. (2003). Using documents in social research. New Delhi, India: Sage.

Prior, L. (2008). Repositioning documents in social research. Sociology, 42(5), 857-872. http://dx.doi.org/10.1177/0038038508094564

Reames, E. (2010). Shifting paradigms: Redesigning a principal preparation program's curriculum. Journal of Research on Leadership Education, 5(12.5), 436-459.

Seashore-Louis, K., Leithwood, K., Wahlstrom, K. L., \& Anderson, S. E. (2010). Investigating the links to improved student learning. Minneapolis, MN: The University of Minnesota.

Soehner, D., \& Ryan, T. (2011). The interdependence of principal school leadership and student achievement. Scholar-Practitioner Quarterly, 5(3), 274-288.

Southworth, G. (2009). Learning-centered leadership. In Davies B (ed) The essentials of school leadership. London, UK: Sage, pp. 91-111. http://dx.doi.org/10.4135/9781446288290.n6

Tirozzi, G. (2004). Repainting the canvas: The changing artistry of the principalship. In Bond I \& Ayers J (eds) Profiles in leadership: Innovative approaches to transforming the American high school. Washington, DC: Alliance for Excellent Education, pp. 42-48.

Tucker, M. (2003). Out with the old. Education Next, 3(4), 20-24.

Tupper, K. W. (2008). Drugs, discourses and education: A critical discourse analysis of a high-school drug education text. Discourse: Studies in the Cultural Politics of Education, 29(2), 223-238. http://dx.doi.org/10.1080/01596300801966864

Weiler, S. C., \& Cray, M. (2012). Measuring Colorado superintendents' perceptions of principal preparation programs. Educational Considerations, 39(2), 66-76.

West, A., Mattei, P., \& Roberts, J. (2011). Accountability and sanctions in English schools. British Journal of Educational Studies, 59(1), 41-62. http://dx.doi.org/10.1080/00071005.2010.529416

Whitaker, K. (2001). Where are the principal candidates? Perceptions of superintendents. NASSP Bulletin, 85(625), 82-92. http://dx.doi.org/10.1177/019263650108562509

Winton, S., \& Pollock, K. (2013). Preparing politically savvy principals in Ontario, Canada. Journal of Educational 
Administration, 51(1), 40-54. http://dx.doi.org/10.1108/09578231311291422

Wojtczak, A. (2002). Glossary of medical education terms: Part 1. Medical Teacher, 24(2), $216-219$. http://dx.doi.org/10.1080/01421590220120722

Yan, W., \& Ehrich, L. C. (2009). Principal preparation and training: A look at China and its issues. International Journal of Educational Management, 23(1), 51-64. http://dx.doi.org/10.1108/09513540910926420 